\title{
SOCIAL SUPPORT FOR THE QUALITY OF LIFE POSTPARTUM MOTHERS IN SUKODONO SUBDISTRICT SRAGEN REGENCY
}

\author{
Faizah Betty Rahayuningsih, Endang Zulaicha $\mathrm{S}$ \\ Program Studi Ilmu Keperawatan, Universitas Muhammadiyah Surakarta \\ E-mail: faizahbetty@ymail.com
}

\begin{abstract}
ABSTRAK
Pendahuluan: Masa pospartum sering kali dianggap sesuatu yang sementara atau tidak penting. Sehingga perawatan postpartum menjadi aspek yang diabaikan dari kesehatan perempuan. Dukungan social penting bagi kesejahteraan ibu dan anak. Penelitian ini bertujuan untuk menguji perbedaan dan pengaruh dari skor dukungan social dan kualitas hidup ibu pospartum dengan kunjungan rumah 1, 2, dan 3. Metode: Penelitian ini menggunakan desain cross sectional dengan pengukuran longitudinal repeated. Sampel penelitian adalah ibu pospartum yang melahirkan di desa Sukodono dari 3 sampai 40 hari. Teknik pemilihan sampel menggunakan purposive sampling. Hasil: Tidak ada perbedaan yang signifikan dari rerata antara empat jenis dukungan seperti suami, orang tua, mertua, dan saudara. $(p>0,05)$. Tidak ada perbedaan yang signifikan pada rerata skor kualitas hidup ibu pospartum $(\mathrm{p}>0,05)$. Analisis regression equality dukungan social terhadap kualitas hidup ibu pospartum menunjukkan hasil pada K1, K2, dan K3 adalah 0,157 + 0,702*husband's support, $0,099+0,370 *$ husband's support $-0,674 *$ relative's support, and $0,123+0,0674 *$ husband's support $-0,633 *$ relative's support. Pembahasan: Dukungan suami secara signifikan meningkatkan kualitas hidup ibu pospartum. Penelitian ini merekomendasikan perencanaan pendidikan oleh bidan dan perawat tentang pentingnya dukungan sosial pospartum pada ibu. Pendidikan persiapan melahirkan diberikan tidak hanya pada ibu melainkan juga pada suami.
\end{abstract}

Kata kunci: dukungan keluarga, kualitas hidup, pospartum

\begin{abstract}
Introduction: Postpartum period is often considered as temporary or unimportant thing. Thus, the postpartum treatment becomes the ignored aspect from the women's health. The social support is important for mother's and child's prosperity. This research is aimed to examine the difference and the influence of social support score and the quality of life postpartum mothers by home visit 1, 2, and 3. Method: This research employs cross sectional design with longitudinal repeated measure design. The sample of this research was postpartum mothers that give birth in the village of Sukodono subdistrict area from 3 to 40 days. The sample is selected by purposive sampling. Results: There is no significant difference of mean between husband's, parents', parents-in-law's, and relative's support $(p>0.05)$. There is no significant difference between the quality of life postpartum mother $(p>0.05)$. The regression equality of social support to quality of life pospartum mother in K1, K2, and K3 were 0,157 + 0.702*husband's support, $0.099+0.370 *$ husband's support - 0.674*relative's support, and 0,123+0,0674*husband's support-0,633*relative's support, respectively. Discussion. Husband's support increase quality of life pospartum mother. This is suggested to plan education in-service about the important of social support after giving birth for midwife or nurse that has role to service the mothers. Giving the education of postpartum preparation is not only for the mothers, but also for their husband.
\end{abstract}

Keywords: relative's support, quality of life, postpartum

\section{INTRODUCTION}

There are no life events that have big effect in physical, emotional, and social condition such as postpartum period (Webb et al., 2008). This transition period is often considered as temporary or unimportant thing (Symon et al., 2003) hence the postpartum treatment becomes the ignored aspect for the women's health (Depkes, 2010). The social support is important for mother's and child's prosperity. The woman adaptation needs social support when the women become the mothers.
Home visit is conducted four times as the support from health workers. Government policy is postpartum mothers' (KF) and neonatus visit. There is possibility of the assessment of social support and the quality of life when home visit is held, but the assessment of social support and the quality of life for postpartum mothers has been conducted yet.

\section{OBJECTIVES}

This research is aimed to examine the difference and the influence of social support 
score and the quality of life postpartum mothers by home visit 1, 2, and 3 in Sukodono subdistrict of Sragen Regency.

\section{METHODS}

This research employs cross sectional design with longitudinal repeated measure design. (K1) 1 data is taken in neonatus period/ $\mathrm{KN}-2$ from 3 to 7 day, (K) 2 data is taken in lochia period/KF-2 and KN 3 from 8 to 28 day, and $(\mathrm{K}) 3$ data is taken in lochia period/KF-3 from 29 to 42 day. The location of this research is conducted in Sukodono subdistrict of Sragen regency. The population of this research is postpartum mothers that give birth in the village of Sukodono subdistrict area. The research sample is postpartum mothers from 3 to 40 days. This research is conducted in June to October 2013. The sample is selected by purposive sampling with the criteria of postpartum mother inclusion that gives birth in pregnancy period $>28$ weeks, have contact with grandmother or grandmother-in-law or respected family and living with husband, and want to be the respondent.

The variable that is used in this research is independent variable, because the social support of postpartum mothers is self illustration that has interaction with the husband or parents and aimed to fulfill needs to be loved, to be respected, and also to be saved. Thus, the mothers will get happiness that can influence mothers' emotion and behavior. Dependent variable is because the quality of life of postpartum mothers is the perception of postpartum mothers for their own quality of life. This is measured based on four sub variables of the quality of life by using the quality of life questionnaire Postpartum Quality of Life (PQOL) from Zhou et al. (2009) that has been tested its validity and its reliability.

The life quality of postpartum mothers uses the instrument such as questionnaire about the quality of life of postpartum mothers by translating the questionnaire Postpartum Quality of Life (PQOL) from Zhou et al. (2009) in Bahasa. Social support for postpartum mother uses the instrument such as questionnaire about social support of postpartum mothers by translating the questionnaire Postpartum Social Support Questionnaire (PSSQ) from Hopkins \& Campbell (2008) in Bahasa. These questionnaires are chosen because they are suitable for social support assessment for postpartum mother. The answer is done by giving score that is appropriate for the perception. The measuring scale with semantic differential scale with answer range between $1=$ never and $7=$ really often. The amount of the score is to see the level of social support of postpartum mothers. The higher score obtained shows the higher social support of postpartum mothers, and vice versa.

Testing the validity and reliability instrument of this research is conducted in June 2013 to 30 research respondents with the sample that is appropriate for inclusion criteria. Validity testing is conducted with correlation testing of Product Moment Person. The question with significant score $>0,05$ is tested again with the different sample until the all of question have significant score $<0,05$. Reliability and validity are tested only once, internal consistency testing, by counting the alpha reliability coefficient, by using two-item scale with Spearman-Brown formula for twoitem scale (Azwar, 2010). Reliability score instrument has completed $r \geq 0,30$, therefore the questionnaire has been reliable to be used in data taken.

The data are collected by numerator by home visit. The assessment is conducted three times such as the first assessment/K1 $\left(3^{\text {rd }}\right.$ to $7^{\text {th }}$ day of postpartum), the second assessment/ K2 ( $8^{\text {th }}-8^{\text {th }}$ day of postpartum), and the third assessment/K3 $\left(29^{\text {th }}-42^{\text {nd }}\right.$ of postpartum). The difficulty and the obstacle are also noted in this research. The possible obstacle is when the mothers are looking after their baby and the only anticipation is waiting till they are free.

\section{The Data Analysis}

The characteristic of postpartum mothers is researched by mothers' ages, educations, and work. The difference score of social support (consisting husband's support, parent's support, parents-in-law's support, 
and relative's support) and the quality of life postpartum mothers in every home visit 1 , 2 , and 3, they are shown in score table that show the minimal-maximal score, mean, range between (gain score), SD, SE, t, P value, and $\mathrm{N}$. The influence of social support (consisting husband's support, parent's support, parentin-law's support, and relative support) and quality of life postpartum mothers when visiting home 1,2 , and 3 , are shown in this table that conconsisting husband's support, parent's support, parent-in-law's support, and relative support) and the quality of life postpartum mothers when visiting home 1,2 , and 3, are shown in this table that contains $\mathrm{R}^{2}$ (R-Square) score, B, influenced variable (X), and $\mathrm{P}$ Value.

\section{RESULTS}

\section{The Characteristic of Respondent}

The sample of this research uses 69 postpartum mothers in Sukodono Subdistrict. The analysis result is the average of mothers' age is about 27,94 years old $(95 \%$ CI:26,63$29,25)$, median on 27 years old with the deviation standard 5,447 years. For the youngest age is 17 years old, and the oldest ages is 43 years old. The result of estimation interval can be concluded that $95 \%$ believed that the mean of mothers' age is between 26,63-29,25 years old.

Almost distribution job of the respondents is housewife about 40 persons $(58 \%)$, and there is only a little amount of farmer that is 2 persons $(2,9 \%)$. The mothers that work as entrepreneurs are 24 persons
$(34,8)$ and civil officers are 3 persons $(4,3 \%)$. Based on the data above, almost all the mothers are housewives, and then entrepreneur, and then farmer.

Almost distribution education of mothers is junior high school for $34,8 \%$ and senior high school for $33,3 \%$. Almost all the education are junior high school, and elementer school 11,6\%, Health Diploma Degree 7,2\%, Bachelor Degree 5,8\%, Senior High School of Health $4,3 \%$, and each for $2,9 \%$.

The Difference of Social Support at Home Visit 1, 2, and 3

\section{Husband's Support}

According to table 1, there is no significant difference between husband's support in measurement $\mathrm{K} 1: \mathrm{K} 2, \mathrm{~K} 2-\mathrm{K} 3$, and K1-K3, with P-Value score $>0,05$. The increasing of mean score of husband's support appears in $\mathrm{K} 1: \mathrm{K} 2$, and $\mathrm{K} 1-\mathrm{K} 3$, but there is decreasing of mean score between $\mathrm{K} 2: \mathrm{K} 3$.

\section{Parents' Support}

According to table 2, there is no significant difference between parents' support in measurement K1-K2, K2-K3, and K1-K3, with $p$-Value score $>0,05$. The increasing of mean score of parents' score appears in all measurement K1: K2, K2-K3, dan K1-K3.

\section{Parents-in-law's Support}

According to table 3, there is no significant different between parents-in-law's support in measurement K1- K2, K2-K3, and $\mathrm{K} 1-\mathrm{K} 3$, with $\mathrm{p}$-Value score $>0,05$. The

Table 1. Husband's support at home visit 1, 2, and 3

\begin{tabular}{lcccccccccc}
\hline \multicolumn{1}{c}{ Variable } & & $\begin{array}{c}\text { Min- } \\
\text { Max }\end{array}$ & Mean & $\begin{array}{c}\text { Gain } \\
\text { score } \\
\text { mean }\end{array}$ & $\begin{array}{c}\text { SD } \\
\text { Score } \\
\text { SD }\end{array}$ & SE & t & $\begin{array}{c}\text { P- } \\
\text { value }\end{array}$ & N \\
\hline Husband's & K 1 & $50-94$ & 70.97 & 1,23 & 10.21 & 9,75 & 1.22 & 1.04 & 0,298 & 69 \\
Support & K 2 & $53-96$ & 72.20 & & 9.14 & & 1.10 & & & \\
& K 2 & $53-96$ & 72.20 & 0,69 & 9.14 & 8,56 & 1.10 & 0.67 & 0,502 & 69 \\
& K 3 & $54-96$ & 71.51 & & 9.16 & & 1.10 & & & \\
& K 1 & $50-94$ & 70.97 & 0,53 & 10.21 & 11,54 & 1.22 & 0.38 & 0,701 & 69 \\
& K 3 & $54-96$ & 71.51 & & 9.16 & & 1.10 & & & \\
\hline
\end{tabular}


Jurnal INJEC Vol. 1 No. 1 April 2014: 45-52

Table 2. Parents' support at home visit 1, 2, and 3

\begin{tabular}{lcccccccccc}
\hline \multicolumn{1}{c}{ Variable } & & $\begin{array}{c}\text { Min- } \\
\text { Max }\end{array}$ & Mean & $\begin{array}{c}\text { Gain } \\
\text { score } \\
\text { mean }\end{array}$ & $\begin{array}{c}\text { SD } \\
\text { Score } \\
\text { SD }\end{array}$ & $\begin{array}{c}\text { Gain } \\
\text { score }\end{array}$ & t & $\begin{array}{c}\text { P- } \\
\text { value }\end{array}$ & N \\
\hline Support & K 1 & $13-60$ & 39.54 & 0,82 & 8.76 & 7,45 & 1.05 & 0.921 & 0,360 & 69 \\
& K 2 & $21-61$ & 40.36 & & 7.50 & & 0.90 & & & \\
& K 2 & $21-61$ & 40.36 & 0,66 & 7.50 & 5,24 & 0.90 & 1.056 & 0,295 & 69 \\
& K 3 & $21-65$ & 41.03 & & 7.69 & & 0.92 & & & \\
& K 1 & $13-60$ & 39.54 & 1,49 & 8.76 & 8,99 & 1.05 & 1.378 & 0,173 & 69 \\
& K 3 & $21-65$ & 41.03 & & 7.69 & & 0.92 & & & \\
\hline
\end{tabular}

Table 3. Parents-in-law support at home visit 1, 2, and 3

\begin{tabular}{lcccccccccc}
\hline \multicolumn{1}{c}{ Variable } & & $\begin{array}{c}\text { Min- } \\
\text { Max }\end{array}$ & Mean & $\begin{array}{c}\text { Gain } \\
\text { score } \\
\text { mean }\end{array}$ & $\begin{array}{c}\text { SD } \\
\text { score } \\
\text { SD }\end{array}$ & $\begin{array}{c}\text { Gain } \\
\text { sE }\end{array}$ & t & $\begin{array}{c}\text { P- } \\
\text { value }\end{array}$ & N \\
\hline Parents- & K 1 & $21-54$ & 33.51 & 0,10 & 7.43 & 5.57 & 0.89 & 0.151 & 0,880 & 69 \\
In-law's & K 2 & $21-56$ & 33.61 & & 7.18 & & 0.86 & & & \\
Support & K 2 & $21-56$ & 33.61 & 0,92 & 7.18 & 5.65 & 0.86 & 1.363 & 0,177 & 69 \\
& K 3 & $21-56$ & 34.54 & & 6.52 & & 0.78 & & & \\
& K 1 & $21-54$ & 33.51 & 1,02 & 7.43 & 7.10 & 0.89 & 1.204 & 0,230 & 69 \\
& K 3 & $21-56$ & 34.54 & & 6.52 & & 0.78 & & & \\
\hline
\end{tabular}

Table 4. Relative's support at home visit 1, 2, and 3

\begin{tabular}{lcccccccccc}
\hline \multicolumn{1}{c}{ Variable } & & $\begin{array}{c}\text { Min- } \\
\text { Max }\end{array}$ & Mean & $\begin{array}{c}\text { Gain } \\
\text { score } \\
\text { mean }\end{array}$ & SD & $\begin{array}{c}\text { Gain } \\
\text { score } \\
\text { SD }\end{array}$ & SE & t & $\begin{array}{c}\text { P- } \\
\text { value }\end{array}$ & N \\
\hline Relative's & K 1 & $26-58$ & 38.99 & 0,33 & 7.21 & 5.39 & 0.86 & 0.513 & 0.610 & 69 \\
Support & K 2 & $26-59$ & 39.32 & & 6.46 & & 0.77 & & & \\
& K 2 & $26-59$ & 39.32 & 1,72 & 6.46 & 4.88 & 0.77 & 2.935 & 0.005 & 69 \\
& K 3 & $23-60$ & 41.04 & & 7.04 & & 0.84 & & & \\
& K 1 & $26-58$ & 38.99 & 2,05 & 7.21 & 7.34 & 0.86 & 2.328 & 0.023 & 69 \\
& K 3 & $23-60$ & 41.04 & & 7.04 & & 0.84 & & & \\
\hline
\end{tabular}

increasing of mean score of parents-in-law's support appears in all measurement K1: K2, K2-K3, and K1-K3.

\section{Relative's Support}

According to table 4 , there is a significant difference between relative's support in measurement K2-K3, and K1-K3, with pvalue score $<0,05$, but there is no difference in measurement K1-K2. The increasing of mean score of relative's score appears in all measurement $\mathrm{K} 1: \mathrm{K} 2, \mathrm{~K} 2-\mathrm{K} 3$, and $\mathrm{K} 1-\mathrm{K} 3$.

\section{The Difference of Quality of Life Postpartum} Mother at Home Visit 1,2, and 3

According to table 5, there is no significant difference between the quality of life postpartum mother in measurement K1$\mathrm{K} 2$, K2-K3, and K1-K3, with p-Value score $>0,05$. The increasing of mean score of life quality appears in $\mathrm{K} 1: \mathrm{K} 2$, and $\mathrm{K} 1-\mathrm{K} 3$, but there is decreasing of mean score between $\mathrm{K} 2: \mathrm{K} 3$. 


\section{The Influence of Social Support for Quality of Life Postpartum Mothers}

\section{Home Visit 1}

The analysis by using backward method, in fact the independent variable that includes in regression model is husband's support. Its equality model is:

The quality of life postpartum mothers $=0,099+0,370 *$ husband's support $0,674 *$ relative's support

Regression coefficient of husband's support is 0,157 states that every additional one score for husband's support, the husband's support will increase the quality of life postpartum mothers around 0,702 , in other words the quality of life postpartum mothers will increase up to 0,702 if the mother has husband's support. Significant test score $\mathrm{t}=$ 0,001 is in husband's support variable. It means it is below 0,025 , therefore the husband's support is significant, but parent's, parents-inlaw's, and relative's support are not significant for the quality of life postpartum mothers.

\section{Home Visit 2}

After conducted the analysis by using backward method, in fact the independent variable that include in regression model is husband's support and relative's support. Its equality model is:

The quality of life postpartum mothers $=$ $0,157+0,702 *$ husband's support

The quality of life postpartum mothers will increase 0,370 if the mother has husband's support, but it will decrease 0,674 if there is relative's support. The biggest influence of variable is relatives.

\section{Home Visit 3}

The conclusion of the analysis by using backward method, infact independent variable that includes in regression model is husband's support and relative's support. Its equality model is:

The quality of life postpartum mothers $=0,123+0,674 *$ husband's support$0,633 *$ relative's support

Table 5. The quality of life of postpartum mothers at home visit 1,2 , and 3

\begin{tabular}{lcccccccccc}
\hline \multicolumn{1}{c}{ Variable } & & Min-Max & Mean & $\begin{array}{c}\text { Gain } \\
\text { score } \\
\text { mean }\end{array}$ & SD & $\begin{array}{c}\text { Gain } \\
\text { score } \\
\text { SD }\end{array}$ & SE & t & $\begin{array}{c}\text { P- } \\
\text { value }\end{array}$ & N \\
\hline $\begin{array}{l}\text { The quality } \\
\text { of life }\end{array}$ & K 1 & $102-185$ & 152.30 & 1,15 & 18.08 & 13.61 & 2,17 & 0,707 & 0,482 & 69 \\
postpartum & K 2 & $107-179$ & 153.46 & & 15.07 & & 1,81 & & & \\
mothers & K 2 & $107-179$ & 153.46 & 0,73 & 15.07 & 13,45 & 2,17 & 0,456 & 0,650 & 69 \\
& K 3 & $116-182$ & 153.04 & & 15.53 & & 1,87 & & & \\
& K 1 & $102-185$ & 152.30 & 0,42 & 18.08 & 10.31 & 1,81 & 0,338 & 0,736 & 69 \\
& K 3 & $116-182$ & 153.04 & & 15.53 & & 1,87 & & & \\
\hline
\end{tabular}

Table 6. The influence of social support for quality of life postpartum mothers

\begin{tabular}{ccccc}
\hline No & Score & Home Visit 1 & Home Visit 2 & Home Visit 3 \\
\hline 1 & $\mathrm{R}^{2}$ & 0,157 & 0,099 & 0,123 \\
2 & $\mathrm{~B} 1$ & 0,702 & 0,370 & 0,674 \\
3 & $\mathrm{X} 1$ & Husband's support & Husband's support & Parents' support \\
4 & $\mathrm{~B} 2$ & & $-0,674$ & $-0,633$ \\
5 & $\mathrm{X} 2$ & & Relative's support & Relative's support \\
6 & $\mathrm{P}$ Value & 0,001 & 0,03 & 0,013 \\
\hline
\end{tabular}


The quality of life postpartum mothers will increase 0,674 if the mother has husband and it will decrease 0,633 if there is relative's support. The biggest influence of variable is husband's support.

\section{The Discussion}

The support from family is needed by the women to adapt in transition period to be a parent. Mother or mother-in-law probably will see the depression and low income, thus they can help to solve the problem ( $\mathrm{Lu}$ et al., 2011). Social support will decrease prenatal depression and will act as savior between potential stressor and care.

Haga et al. (2012) identified three aspects of social support that will be used. They are emotional, informational, and instrumental support. There is a relation between postpartum depression with emotional and instrumental support consistently. Depressed women reported that they get less support after they give birth than when they are being pregnant. Postpartum depression event especially is because less emotional support from husband and mother from the women that gets postpartum depression, and also practical help from the husband. (Dennis \& Ross, 2006), and interaction between mother and father $(\mathrm{Lu}$ et al., 2011).

A father will more satisfied if their marriage has the children and they will have more positive attitude as the father, but the satisfaction of marriage has no relation with adaptation of the mother since postpartum period. (Lu et al., 2011). Social support has positive influence when the women give birth and it prooves as the factor of avoiding postpartum depressi (Evans et al., 2011). Depression is the significant indicator of emotional and instrumental social (Boothe et al., 2011).

Prevalence of postpartum depression is $13,2 \%$ for 6 weeks and $9,8 \%$ for 12 weeks. Formal structural support and functional emotional support when the mother give birth are the prediction of postpartum independent depression, and for 6 and 12 weeks of postpartum social support dimension that relates with it is social and functional support (Leahy-Warrn et al., 2011)

Postpartum support (Gulick, 2008) consists of: 1) emotional support such as empathy, care, love, and trust. 2) Informational support such as giving the information that can be used to solve the problem like take caring baby, self treatment and personal problems or other environment. 3) Instrumental support such as giving help to take caring baby and do the housework.

Development of the family is important to adapt with the family itself. The proper treatment such as support from the family along for postpartum period can facilitate the adaptation of a mother ( $\mathrm{Lu}$ et al., 2011). Development of the family and married satisfaction are reported as the adapting factor from mother and father for postpartum period, and expressing love and care to a new mother.

The possible influence of culture and principle should be considered by healthy professional that develops the strategy to facilitate family adaptation with young parents(Lu et al., 2011). Antenatal and postnatal education program are the part of family that is a center of treatment. There is a possibility for the fathers to participate in treatment after the mother give birth (Oommen at al., 2011).

\section{CONCLUSION AND THE RECOM- MENDATION}

\section{Conclusion}

Husband's support increase quality of life pospartum mother. This research is to explain about the challenge when giving support that is needed for the mothers to increase their health and to help planning of the program.

\section{Recommendation}

This is suggested to plan education inservice about the important of social support after giving birth for midwife or nurse that has role to service the mothers. 
Giving the education of postpartum preparation is not only for the mothers, but also for their husband.

\section{REFERENCES}

Azwar, S. 2010. Reliabilitas dan Validitas. Yogyakarta: Pustaka Pelajar.

Bahadoran, P., Abbasi, F., Yousefi, A.R. \& Kargarfard, M. 2007. Evaluating the Effect of Exercise on the Postpartum Quality of Life. Iranian Journal of Nursing and Midwifery Research Winter 12(1).

Bahadoran, P., Azimi, A., Valiyani, M. \& Ahmadi, S.A. 2009. The relation between sosial support and postpartum physical health in mothers. IJNMR. 14(1).

Boothe, A.S., Brouwer, R.J., Carter-Edwards, L. \& Ostbye, T. 2011. Unmet sosial support for healthy behaviors among overweight and obese postpartum women: results from the Active Mothers Postpartum Study. J Womens Health (Larchmt), 20(11): 1677-85.

BPS. 2011. Sragen Dalam Angka Tahun 2011. Badan Pusat Statistik. Sragen

Campbell D.T. \& Stanley J.C. 1972. Experimental and Quasi-Experimental Coyle, S.B., 2011. Maternal concern, sosial support, and health-related quality of life across childhood. Res Nurs Health. 2011 Aug; 34(4): 297-309.

Dennis, C.L. \& Ross, L. 2006. Women's perceptions of partner support and conflict in the development of postpartum depressive symptoms. $J A d v$ Nurs, 56(6): 588-99.

Depkes. 2010. Riset Kesehatan Dasar: Riskesdas 2010. Jakarta: Badan Penelitian dan Pengembangan Kesehatan Kementerian Kesehatan RI design for Research. Rand McNally \& Company. Chicago.

Evans, M., Donelle, L. \& Hume-Loveland, L. 2011. Sosial support and online postpartum depression discussion groups: A content analysis. Patient Educ Couns.

Gulick, E.E. 2003. Adaptation of the postpartum support questionnaire for mothers with multiple sclerosis. Res Nurs Health. 26(1): 30-9.

Haga, S.M., Ulleberg, P., Slinning, K., Kraft, P., Steen, T.B. \& Staff, A. 2012. A longitudinal study of postpartum depressive symptoms: multilevel growth curve analyses of emotion regulation strategies, breastfeeding self-efficacy, and sosial support. Arch Womens Ment Health.

Hill, P.D., Aldag, J.C., Hekel, B., Riner, G. \& Bloomfield, P. 2006. Maternal Postpartum Quality of Life Questionnaire. J Nurs Meas, 14(3): 205-20.

Hopkins, J. \& Campbell, S.B. 2008. Development and validation of a scale to assess sosial support in the postpartum period. Arch Womens Ment Health. 11(1): 57-65.

Joan Webster, Catherine Nicholas, Catherine Velacott, Noelle Cridland, Lisa Fawcett, Quality of life and depression following childbirth: impact of sosial support, Midwifery, Volume 27, Issue 5, October 2011, Pages 745-749.

Leahy-Warren, P., McCarthy, G. \& Corcoran, P. 2011. Postnatal depression in first-time mothers: prevalence and relationships between functional and structural sosial support at 6 and 12 weeks postpartum. Arch Psychiatr Nurs, 25(3): 174-84.

Lemeshow, S. Hosmer, D.W., Klar, J. \& Lwanga, S.K. 1997. Besar Sampel dalam Penelitian Kesehatan Yogyakarta: Gadjah Mada university Press.

Lu, Q., Uysal, A. \& Teo, I. 2011. Need satisfaction and catastrophizing: explaining the relationship among emotional ambivalence, pain, and depressive symptoms. J Health Psychol. 16(5): 819-27.

Ri-Hua Xie, Guoping He, Diana Koszycki, Mark Walker, Shi Wu Wen, Prenatal Sosial Support, Postnatal Sosial Support, and Postpartum Depression, Annals of Epidemiology, Volume 19, Issue 9, September 2009, Pages 637-643.

Sugiyono. 2011. Metode Penelitian Kuantitatif, Kualitatif, dan $R \& D$. Penerbit Alfabeta. Bandung. 
Symon, A. 2003. A review of mothers' prenatal and postnatal quality of life. Health Qual Life Outcomes. 138.

Webb, D.A., Bloch, J.R., Coyne, J.C., Chung, E.K., Bennett, I.M. \& Culhane, J.F. 2008. Postpartum physical symptoms in new mothers: their relationship to functional limitations and emotional well-being. Birth. 35(3): 179-87.

Webster, J., Nicholas, C., Velacott, C., Cridland, N. \& Fawcett, L. 2011. Quality of life and depression following childbirth: impact of sosial support. Midwifery. 2011 Oct; 27(5):745-9.

WHO. 2008. WHO Technical consultation on postpartum and postnatal care. Geneva.
Wilson, I.B. \& Cleary, P.D. 1995. Linking clinical variabels with health-related quality of life. A conceptual model of patient outcomes. JAMA. 273(1): 59-65.

Yanita. A. \& Zumralita. 2001. Persepsi perempuan primipara tentang dukungan suami dalam usaha penanggulangi gejala depresi pascasalin. Phornesis Jurnal ilmiah dan terapan. Publikasi Fakultas Psikologi universitas Tarumanegara, 3, 23-40. Surabaya Indonesia

Zainur, R.Z. \& Loh, K.Y. 2006. "Postpartum morbidity-what we can do". Med $J$ Malaysia. 61(5): 651-6.

Zhou, S.Z., Wang, X.L. \& Wang, Y. 2009. Design of a questionnaire for evaluating the quality of life of postpartum women (PQOL) in China. Qual Life Res. 18(4): 497-508. 